\title{
THE EARL MARSHAL, THE HERALDS, AND THE HOUSE OF COMMONS,
} I $604-I 64 I^{1}$

The successful reassertion of the authority of the Court of the Earl Marshal, in the recent case of the Corporation of Manchester vs. The Manchester Palace of Varieties, Ltd., has renewed interest in this ancient institution. The court ruled that The Manchester Palace of Varieties had wrongly displayed the heraldic arms of the Corporation, contrary to the laws and customs of arms, and that the court itself, which had last sat in $175 \mathrm{I}$ and which Blackstone described as having fallen into contempt and disuse, was still empowered to give relief to those who thought themselves aggrieved in such matters. ${ }^{2}$

A full account of the Court of the Earl Marshal is much to be desired. ${ }^{3}$ It cannot be attempted in the space of this paper, but one period

1 The author gratefully acknowledges a summer fellowship at the Folger Shakespeare Library which enabled him to do part of the research. Mr. G. D. Squibb and Mr. S. E. Thorne kindly gave advice on certain points.

2 The Times (London), 22 Dec. 1954 and 22 Jan. 1955; The Full Report of the Case of the Mayor, Aldermen and Citizens of the City of Manchester versus the Manchester Palace of Varieties Limited in the High Court of Chivalry on Tuesday, 2 Ist December, 1954, The Heraldry Society, East Knoyle, Salisbury, I955.

3 There is a voluminous literature on heraldry, some of which deals with the earl marshal. The best guide is Thomas Moule, Bibliotheca Hetaldica Magnae Britanniae, London 1822 ; see also S. Trehearne Cope, Heraldry, Flags and Seals: A Select Bibliography, with Annotations, Covering the Period I 920 to I 945, in: Journal of Documentation, IV (1948), 92-I 46. John Anstis, Curia Militaris: or, a Treatise of the Court of Chivalry; in three books (printed, not published, London 1702) contains only the introduction and table of contents of a work which was never completed. Thomas Hearne, A Collection of Curious Discourses, London 1720; 2nd ed., 2 vols., 1765 ; 3 rd ed., I 771 , includes several contemporary papers on the earl marshal, composed in the first years of the seventeenth century. Other useful works are Joseph Edmondson, A Complete Body of Heraldry 2 vols., London 1780 ; James Dallaway, Inquiries into the Origin and Progress of the Science of Hetaldry, Gloucester 1793; and Mark Noble, A History of the College of Arms, London 1805 . The fullest modern account is by George Grazebrook, The Earl Marshal's Court in England; comprising Visitations, and the Penalties incurred by their Neglect, in: 'Trans. Hist. Soc. Lancashire and Cheshire, n.s., IX (1894), 99-140, also printed separately (Liverpool, I 895). Many of the visitations have been published by the 
of its history, when its powers were most radically curtailed, may be described. This was the period I604-164I, culminating in the attack by the Long Parliament. It is true that no statutory reduction of its jurisdiction was enacted; nevertheless the court emerged very considerably shorn of its authority, being reduced from a powerful tribunal which contested for jurisdiction with the highest courts of the realm to a body which is exclusively heraldic, and which only barely clung to its existence in the years after 1660 . At the same time the powers of the College of Heralds were similarly curtailed. The action which led to these changes was part of the larger controversy over the common law, for it stemmed from the sentiment that the conduct of the heralds and the earl marshal's court constituted an invasion of common law rights. The new restrictions are also to be explained in terms of the social stresses which underlay the struggles of the midseventeenth century, for they were partly produced by resentment among certain classes of society at the attempt of a special agency to maintain class privilege.

The earl marshal and the other heraldic officials were of medieval origin. The marshal, together with the constable of the kingdom, exercised the military jurisdiction of the crown over the feudal array in time of war. They held courts for the trial of offences against the laws of war and for the decision of certain civil causes as well. The earl marshal also exercised a special jurisdiction within the king's household, whereby he tried suits between members of the household and offences committed within the verge of the court, as the area within the radius of twelve miles was called. The Marshalsea prison was a survival of this jurisdiction, although the authority in this respect had passed to lesser officials by the Elizabethan period. Much of the business of the constable and marshal was concerned with disputes as to precedence, the right to bear coat armor, and the superintendance of tournaments and duels. At first their jurisdiction appears to have been exercised only in France, during the English invasions, but during the Wars of the Roses the victors sometimes employed the court to punish the vanquished, rather than resort to trial by jury on charges of treason. ${ }^{1}$ A number of statutes of the fourteenth century aimed at restricting the court to its original jurisdiction, and by the Tudor period it had been pretty well so limited, particularly by $\mathrm{I}_{3}$

Harleian Society. Grazebrook held that the records of the earl marshal's court had disappeared, but some Act Books for $1687-1702$, together with a number of other original documents survive in the College of Arms. These are described in the authoritative work of the present Richmond Herald, Anthony R. Wagner, The Records and Collections of the College of Arms, London I95 2.

1 J. R. Tanner, ed., Tudor Constitutional Documents, Cambridge 1922, pp. 342, 348-49. 
Richard II, St. I, c. 2, which excluded from the court of the constable and marshal any plea triable under common law. The Lord High Constable ceased to exist as a permanent official after $152 \mathrm{I}$, and the court came to be known simply as the earl marshal's court, or the court of honor, or the court of chivalry.

Below the marshal came the officers of arms. These actually managed the jousts and administered the heraldic authority. They were incorporated by Richard III into the College of Heralds, which survives today in the College of Arms. At the head was Garter, Principal King at Arms, authorized to correct errors or usurpations in armorial bearings and to grant arms to such as deserved them. Then there were two Provincial Kings at Arms, Clarenceux (for the region south of the Trent) and Norroy (for the north). The number of ordinary heralds varied from time to time, but there were usually at least six, Windsor, Chester, York, Somerset, Richmond, and Lancaster. These were assisted by a number of pursuivants, such as Rouge-Croix, Blue Mantle, Portcullis, and Rouge-Dragon. From the reign of Henry VIII the heralds systematically undertook, under royal commission, at intervals of about a generation, visitations, or circuits throughout the kingdom in pursuance of the functions above described, and this soon became their principal activity. Armorial bearings had become unnecessary insofar as the military forces were concerned, but the demand for them had vastly increased with the social changes incident to the economic developments of the fifteenth and sixteenth centuries, and the concomitant rise of the gentry.

Elizabeth I granted new statutes governing the College of Heralds in $1568,{ }^{1}$ but during her reign these officers began to fall into disrepute, largely because of the debasement of arms which took place, and because of internal dissension within the College itself. In matters of pedigree the wildest claims were advanced and duly registered. As Round observed, "The Queen herself had set the example with a Tudor pedigree deduced from Adam. The great Burghley was pedigree-mad and sought for the upstart Cecils' ancestors in all directions." Documents were freely forged; charters and seals were cheerfully produced to order. James I followed suit; he eagerly received a pedigree tracing his descent from "Brute, the most noble founder of the Britons." 2 As the present Richmond Herald has explained, "The fashion among the gentry (especially those whose gentility was new) for elaborate pedigrees and heraldic display caused the heralds to cultivate to an altogether new degree this side of their profession." ${ }^{3}$ The debasement

1 Edmondson, Complete Body of Heraldry, I, r 43-47.

a J.H.Round, Family Origins and Other Studies, ed. William Page, London 1930,pp. 5-6.

3 Wagner, Records and Collections of the College of Arms, p. I 5. 
of arms under Elizabeth is well illustrated by the account of Ralph Brooke, York Herald, deploring the improper grants of Sir William Dethick, Garter. Dethick, wrote Brooke, granted the ancient arms of the family of Chamberlayne to one Smyth, an innkeeper of Huntingdon. The arms of Leigh of Staffordshire Dethick granted to Robert Lee, Sheriff of London, the son of a poor tanner in the country, who came to the city with but four groats in his purse. ${ }^{1}$ Similar complaints against his fellows came from William Wyrley, who became Rouge-Croix pursuivant in I604: "Every man that obtaineth large possessions, whether the same be acquired by this judgment in law, traffic in merchandize, or any other mean, yea although never any of his progenitors from whom he can derive himself had the charge to lead men of arms, will yet at this day intrude themselves into the badges and marks of soldiers." 2

Such complaints only vaguely suggest the intense strife which prevailed among the heralds. Controversy over the impropriety of these grants was intensified by quarrels over the division of the fees accruing to the officials of the College of Arms. The annual stipends were merely nominal, ${ }^{3}$ and the heralds, like other government officials, sought their real reimbursement in fees and perquisites. These payments were demanded from persons elevated to the knighthood or peerage or episcopal bench; there were also gifts which the heralds expected at the occasional tilts and jousts, and various fees which they claimed by virtue of their duties at funerals, visitations, and the like. Yet from the highest to the lowest subject the greatest reluctance was demonstrated in paying. The king himself, ran an account of I 609, detained the fees due at his coronation, at the christening of his children, and at the creation of peers. The knights were accused of failure to pay theirs at their dubbing and at their first participating in the tilt. Gentlemen "refuse at the visitation to come to have their descentes entred, whereby they wrong their posterity and the heroldes, in that the heroldes cannot tell them their descent and then they accompte the heroldes ignorante fooles." 4

Plagued by internal dissension, and slighted by the nobility and gentry, the heraldic officials must have counted for little in the popular estimation. Yet there was general agreement on the necessity for some device to differentiate between gentleman and upstart. "How should

1 Folger Shakespeare Library MS. 423.x.

2 William Wyrley, The True Use of Armorie, London I 592, qu. in Sir William Dugdale, 'The Antient Usage in Bearing of such Ensigns of Honour as are commonly call'd Arms, 2d ed., Oxford I682, p. 30.

3 They are listed in Capt. Lazarus Howard, The Charges Issuing forth of the Crown Revenue, London I647, p. 22.

4 Public Record Office, S. P. I 4/44, 77. 
we give nobility her true value, respect, and title, without notice of her merit?" asked Henry Peacham in his well-known handbook to gentility. "And how may we guess her merit without these outward ensigns and badges of virtue, which anciently have been accounted sacred and precious; withall, discern and know an instruding upstart, shot up with the last night's mushroom, from an ancient descended and deserved gentleman, whose grandsires have had their shares in every foughten field by the English since Edward the First?" 1

The earl marshalship was vacant at the accession of James $I$, but in 1604 the king vested it in a commission of six peers, and periodically during the next fourteen years this commission was renewed. ${ }^{2}$ During these years the commissioners held courts frequently. ${ }^{3}$ The most notable cases were concerned with the trial of claims to various peerage dignities, ${ }^{4}$ but they also heard disputes over the right to coat armor and over precedency between various persons. There were controversies between the Knights Bachelor and the Knights of the Bath; ${ }^{5}$ between Serjeants-at-Law and Knights $;{ }^{6}$ between the children of various peers ${ }^{7}$ between knighted aldermen of London and other knights $;{ }^{8}$ and between officials in municipal corporations. ${ }^{9}$ Together with the heralds the court performed a number of ceremonial functions, such as those connected with the degradation of Sir Francis Mitchell from his knighthood, the creating of Prince Charles Prince of Wales, the opening of parliament, and the supervision of tilts and tournaments.

Another activity of the commissioners was the settlement of quarrels between gentlemen who might resort to duelling. Once they had intervened, such quarrels were supposed to be regarded as extinct. Yet, ran a proclamation of ${ }^{2} \mathrm{I}_{3} 3$, it had become a common custom for men barred from a duel to publish their vindications, which was

1 Peacham's Compleat Gentleman, I634, intro. by G. S. Gordon, Oxford I906, pp. I60-6r.

2 Commission of 1604, Calendar of State Papers, Domestic Series, 1603-10, London I 857 , p. 74 (hereafter cited as C.S.P., Dom.); commission of 1605 , Thomas Rymer and Robert Sanderson, eds., Foedera, London 1704-32, XVI, 608; commissions of 1616, ibid., XVI, 779-80, and C.S.P., Dom., I6r I-r8 (1858), p. 395; commissions of 1617 , ibid., p. 44I, and Rymer, XVII, 3-4; commission of I 61 8, Rymer, XVII, 63-64.

3 Public Record Office, S. P. $14 / 44,76,107 ; 16 / 468, x 29$.

4 J. H. Round, Peerage and Pedigree, London I910, I, 69, 86, 91-96. Under Charles I claims to peerage dignities appear to have been tried in the House of Lords.

5 Hist. MSS. Comm., Le Fleming MSS., London 1890 , p. 13.

6 C.S.P., Dom., I6 I I-18, p. 82.

7 Ibid., P. I57.

8 Ibid., p. I 66.

9 Acts of the Privy Council of England, n.s., 1617 -19, London 1929, pp. 3 10-1 I ; C.S.P., Dom., I619-23 (1858), pp. I7, 123 . In I620, when James visited St. Paul's in state, there was a dispute as to whether knighted councillors should follow earls' sons as decided by the commissioners (ibid., p. 135). 
"a treble offence." Therefore it was ordered that offenders in this wise should be punished by the Star Chamber, banished from court for seven years, and accounted by the king as cowards. The proper appeal lay to the Commissioners for the Earl Marshalship, ${ }^{1}$ and there is some evidence that they did intervene in such quarrels. ${ }^{2}$

Not the least of their services was the attempt of the commissioners to preserve peace among the heralds and to bring order into the granting of arms. Their commission recited that "divers errors are committed by certain heralds now deceased, and some such as do live, to the dishonor of our nobility and chivalry." The commissioners ousted Sir William Dethick, Garter, one of the more notorious offenders, and appointed in his place William Segar, who held the office for the next thirty years. They committed to the Marshalsea William Penson, Lancaster Herald, for molesting his fellow officers in suits at law. ${ }^{3}$

A more fundamental cause of disorder engaged their attention continuously. This was the activity of interlopers who undertook to make pedigrees and devise arms. The principal offenders were independent painters, marblers, glaziers, embroiderers, and engravers of seals. An interesting manuscript account elucidates their practices. It is by William Smith, Rouge-Dragon pursuivant. "Every painter's shop is now become an office of arms," he complains. Upper and lower Cheshire each had its painter, "who playeth the provincial herald," and who undertook to supervise funerals, which were conducted with pomp and ceremony so magnificent that, as Smith says, "I never knew any nobleman buried with the like." ${ }^{4}$ Students of the drama are familiar with Smith's account, since in it he complains that common actors have been granted arms. "Phillips the player had graven in a gold ring the arms of Sir W'm Phillipp, L. Bardolf, with the said Lord Bardolf's coat quartered .... Pope the player would have no other arms but the arms of Sir Tho. Pope, Chancellor of the Augmentations." Such examples were offences against the dignity of heraldry; moreover, by them the interlopers deprived the heralds of fees which were rightly theirs. "Nowadays," says Smith, referring to funerals, "so soon as any gentleman is dead the painter getteth the work, before any herald knoweth of it." The attempt was made to restrict heraldic painting to certain members of the Painter-Stainers

1 Proclamations of 15 Oct. $x_{6} x_{3}$ and 4 Feb. I6 $x_{3} / x_{4}$, R. R. Steele, ed., A Bibliography of Royal Proclamations of the Tudor and Stuart Sovereigns, Oxford I9 10, I, nos. I I 34, I 142.

2 C.S.P., Dom., I6I1-1 8, p. 213 ; 1619-23, pp. 2, 436.

3 Public Record Office, S. P. $14 / 44,76$.

4 "A Breeff Discourse of the causes of Discord amongst the officers of armes: and of the great abuses and absurdities comitted by Painters, to the great prejudice and hindrance of the same office," written in I606, Folger Shakespeare Library MS. I I 86. I. 
Company, but it proved impossible to prevent interloping, and the controversy continued throughout the century. ${ }^{1}$

The court of earl marshal was put on a new basis in 1621 , with the appointment of Thomas Howard, Earl of Arundel and Surrey, as sole earl marshal. ${ }^{2}$ Arundel, better known as a collector and patron of the arts, had been a member of the commission since I6I6. He was regarded, favorably by James I as we may suppose, as a preeminent representative of the older nobility as against the nouveaux riches. ${ }^{3}$ It was typical of the man that he should have taunted Lord Spencer in the House of Lords for his ancestor's having kept sheep. He had recently distinguished himself in the eyes of the king by defending Buckingham in the Lords, and his appointment in $162 \mathrm{I}$ is thought to have been his reward. ${ }^{4}$ The terms of his patent were very broad, and seemed to revive a jurisdiction unknown for many years. The Lord Keeper, in fact, protested against what he styled "a power limited by no law, or record, but to be searched out from chronicles, antiquaries, heralds, and such obsolete monuments, and thereupon held these sixty years.... unfit to be revived by the policy of this state." 5 The question of the judicial authority of the earl marshal was already in the air, and one of Arundel's first tasks was to secure a favorable settlement in this respect. Contemporary constitutional writers, such as Cowel in his Interpreter, ${ }^{6}$ and Coke in his Institutes, ${ }^{7}$ agreed broadly as to the authority of the court of earl marshal over military offences, including the power to decide by combat questions of appeal of treason ${ }^{8}$, and the curious power to try appeals of murder committed beyond the sea. Coke, indeed, expressly praised this aspect of the

1 W. A. D. Englefield, The History of the Painter-Stainers Company of London, London I923, pp. $8 \mathrm{I}$ et seq. The painters argued in support of their claims that their art went back to the prophets Jeremiah and Ezekial (C.S.P., Dom., I635-36 [1 866], p. 38).

2 Rymer, XVII, 32 I-22.

3 Mary F. S. Hervey, The Life, Correspondence \& Collections of Thomas Howard, EarI of Arundel, Cambridge I 921 .

4 S. R. Gardiner, History of England from the Accession of James I to the Outbreak of the Civil War, London $1883-84$, IV, $137-38$; C. H. Firth, The House of Lords during the Civil War, London 1910, pp. 39-40.

5 Williams to Buckingham, I Sept. I62I, Cabala, sive scrinia sacra: Mysteries of State and Government, 3rd ed., London I69x, pt. i, 26r-62.

b John Cowel, The Interpeter (first pub. 1607), London I70I, s.v. Constable and Court of Chivalry.

7 The First Part of the Institutes, London 1628 , secs. 102, 745 .

8 The famous hearing, in 1630 , between Lord Reay and David Ramsay, was occasioned by an appeal of treason, and was ordered to be settled by combat, although eventually the king intervened and the parties were committed to the Tower until they gave security to keep the peace. But in this instance the court was enlarged by the special appointment of a Constable (John Rushworth, Historical Collections, II [London, I 680], pt. i, I I 2-28). 
court's jurisdiction. In a letter to the king in ${ }^{6}{ }_{1} 7$ he said that a person who had killed another in a duel beyond seas should be tried before the earl marshal: "And I take this resolution to be well warranted by the statute", he continues, "and no small inconvenience should follow, and a great defect should be in the law, if such bloody offences should not be punished, and your Majesty should lose a flower of your crown, in losing this power to punish these growing and dangerous offences." 1 On the other hand, the non-military jurisdiction of the court of earl marshal was being attacked by the common lawyers. Some went so far as to argue that the law enforced by the earl marshal was a branch of the common law:

"First they labour to prove that the Courte Marshall \& all causes incident to the same are within the compasse of the Common Lawe \& to this end they pduce this Argument. This kingdome of England is onely governed by too Lawes the Common \& Eccleziasticall lawe, the Marshall lawe is in use and practise within the kingdome of England; therefore the Marshall lawe must either be Comon or Ecleziasticall Lawe. So that Admitting this argument \& approving the Statute of the I 3 of R: 2 wch cannot be denied, wherein the Courte Marshall is restreyned \& limited not to hold plea of any Causes triable at the Com lawe, it must consequently follow that the Courte Marshall havinge noe dependence of these too lawes, by wch the kingdome is onely governed cannot be but superflouse \& unnecessary \& might well be spared, which is the ground and scope of there argument."

This notion, the account ran, was expressed by the judges of the common law courts in their published opinions, "wherein they set downe many pticular Cases betwene the Court Marshall \& the Common Lawe but Conclude to the dissabling of the on[e] \& Strenthning of there owne." 2

Another potent cause of the enmity of the common lawyers was their exclusion from practising before the court of earl marshal, which was limited to the civilians. ${ }^{3}$ Probably it is fair to conclude that in these disputes the letter of the law was on the side of the earl marshal, although the sweeping nature of the jurisdiction conferred by Arundel's patent must have been alarming, while the enforcement of fines and penalties in respect to visitations, which were of fairly recent origin, was suspiciously close to the practise, already decried in other

${ }^{1}$ Cabala, pt. i, 200-I.

2 Public Record Office, S. P. I4/124, 38.

${ }^{3}$ Hist. MSS. Comm., Sixth Report (1878), p. 250. 
areas, of creating new crimes and punishments outside parliament. A conflict with the established courts seemed inevitable; indeed it had already been foreshadowed by internal quarrels within the College of Heralds over the jurisdiction of the earl marshal. Dethick, for example, in petitioning against his discharge in 1604 , had appealed to parliament and the council rather than recognize the right of the commissioners for the earl marshal, whose authority extended, he said, to arms and chivalry but not to an office or its fees and profits. ${ }^{1}$ The case of Ralph Brooke, York Herald, was based on the absolute denial of the jurisdiction of the earl marshal's court. Brooke had become York Herald in 1593 . His long quarrel with the other members of the College had taken various forms, such as a virulent attack on Camden, Clarenceux King at Arms, whose Britannia Brooke subjected to close and hostile criticism. In 1613 Brooke sued in Chancery Henry St. George, Blue Mantle Pursuivant, for certain fees which Brooke charged were due to the heralds collectively. St. George denied the jutisdiction of Chancery on the ground that as both parties to the suit were officers at arms the jurisdiction properly lay with the court of earl marshal. Brooke not only denied this, but went on to argue that there neither was nor ever had been any such court as the earl marshal's, but only the court of constable and marshal, and that as there was now no constable it was improper for his (and presumably any other) charges to be tried before such a body as the defendant described. Sir James Whitelocke, Brooke's attorney, has left a first-hand description of the ensuing events. The Chancellor scornfully brushed aside Whitelocke's argument and denounced all lawyers who studied the prerogative. He then carried the matter to the king in person, informing him, as Whitelocke tells us, "that his regal power and princelike prerogative, a point not fit for any subject to meddle withall, was much impeached by it." Whitelocke was committed to the Fleet, and Brooke's case languished for several years. ${ }^{2} \mathrm{He}$ is next heard of in 1619 , when he published a catalogue of the peerage said by the commissioners for the earl marshal to contain numerous gross errors, and ordered by them to be suppressed. ${ }^{3}$ Shortly afterwards Brooke again sued other members of the College of Heralds in the Court of Chancery and in the Court of Common Pleas, continuing to deny the lawful existence of the court of earl marshal.

This was the state of affairs when Arundel was appointed sole earl

1 Hist. MSS. Comm., Salisbuty MSS., XVIII (1940), 68, I 27.

${ }^{2}$ Liber Familicus of Sir James Whitelocke, ed. John Bruce (Camden Soc., o.s., LXX, 1858 ), pp. 34-39.

3 Acts of the Privy Council, I6r 7-19, pp. 338-39. 
marshal. The issue of his authority to hold courts was dealt with before the council. The council committed Brooke to the Marshalsea, ordered a stay of proceedings in the Common Pleas, and ruled, in July 1622, that no doubt existed as to the lawfulness of the earl marshal's court. ${ }^{1}$ Accordingly the king in the following month directed Arundel to proceed in all cases as judicially and definitely as any previous constable or earl marshal. ${ }^{2}$ Brooke remained in confinement until ${ }_{1} 623$, when he was released on acknowledging his error. ${ }^{3}$

Arundel was now free to put into effect the broad patent by which he held office. His first step was to reorganize the court and to prescribe the fees payable for its services. A schedule of these, approved by the king and declared lawful and moderate, exists in the Folger Shakespeare Library. They do not appear to be excessive, although by reason of the number and variety of steps involved it is clear that litigation before the court might become costly. ${ }^{4}$

The first case was heard in November 1623 . Arundel, in what is described as a "good pithy speech," opened the proceedings by speaking of "the long discontinuance of his office," and saying that he was "intent to revive that which had long been in the dust." He had, he asserted, made searches into precedents in order not to encroach upon the other courts; in return he hoped that other courts would not encroach on his. ${ }^{5}$ The first case was not a happy inauguration. It concerned Sir Thomas Harris, a Shropshire baronet, son of a Shrewsbury draper, whose title had been procured through one of Buckingham's brothers, and whom his neighbors petitioned against as unfit to hold that dignity. The king entered the case personally, saying that it had not been intended to elevate any to that order who had not descended at least from a grandfather who was a gentleman, and directing Arundel judicially to degrade any wrongfully promoted. ${ }^{6}$ Harris' case dragged on for more than a year. The defendant protested in vain against the jurisdiction of the court. After many months Arundel declared him to be no gentleman, but discovered that he could not revoke his patent as baronet since it had passed under the Great Seal. ${ }^{7}$ Harris then appealed to the king, and Buckingham

1 Ibid., 1621-23 (1932), pp. 98-100, 364-66; C.S.P., Dom., I619-23, pp. 321, 412, 4I3; Robert Plot (Mowbray Herald Extraordinary in 1695), A Defence of the Jurisdiction of the Earl Marshal's Court, in: Thomas Hearne, A Collection of Curious Discourses, 3 rd ed., London 177 I, II, $265-67$.

2 C.S.P., Dom., $1619-23$, p. 436.

3 Acts of the Privy Council, I62 I-23: p. 450.

4 Folger Shakespeare Library MS. 393.4.

5 Grazebrook, The Earl Marshal's Court, p. i 2 .

6 C.S.P., Dom., 1623-25 (1859), p. 95.

"Ibid., p. 40I. 
appointed referees to examine the proofs of gentility. Harris produced records which satisfied these authorities, but it was apparently impossible to secure a reversal of the original verdict. ${ }^{1}$

Such a case as Harris' might leave one or two disgruntled persons, but in 1622 and 1623 steps were taken which outraged hundreds. In those years eight counties were visited by the heralds, whose conduct, now that they had the authority of Arundel's court behind them, was denounced as more arbitrary than ever. These visitations without exception were conducted by deputies rather than by the appropriate King at Arms. The procedure was for the deputy to write to the bailiff of each hundred in advance, ordering him to warn the knights, esquires, and gentlemen of the hundred to appear before him with the records supporting their claims to their ranks and arms. These were then examined and the pedigree of each family represented was copied into the heralds' books, and lastly the inevitable fee was collected. Persons who failed to appear were ordered to attend the court of the earl marshal; those who failed to produce acceptable evidence of their claims to gentility were publicly disclaimed and warned against further using their pretended titles or arms. The heralds were empowered to deface or pull down any false coats of arms displayed by these pretenders, but there is ample evidence that as soon as they were out of the way these shields were set up again and the arms again displayed on seals, furniture, and the like. ${ }^{2}$

These visitations came under sharp attack in the parliament of 1624 . One other activity of the heralds was likewise denounced: this was their conduct with respect to the funerals of persons of rank. These funerals were likely to be affairs of great pomp, and as the managing of them was usually left to the heralds, who claimed all sorts of perquisites, their profit from a costly funeral was likely to be large. In addition to a flat fee, they claimed reimbursement for their gowns, their servants' livery, their transportation (at I $2 d$. per mile), and on top of all, they often provided the black cloth, hearse, banners, standards, pennons, escutcheons, and crests which had to be purchased and without which any funeral of a peer, at least, would have been regarded with suspicion. There was no law which made the employment of the heralds at funerals mandatory, but any attempt to economize was certainly frowned on if a diminution of ceremony were involved. Nocturnal burials permitting economies were complained of to the Archbishop of Canterbury. ${ }^{3}$ More important, by a procla-

1 Ibid., p. 506.

2 An excellent account of the procedures is given in the introduction to George Grazebrook and John Paul Rylands, eds., The Visitation of Shropshire.... 1623 (Harleian Soc., 3 Noble, History of the College of Arms, pp. 191-92. 1889). 
mation of ${ }_{1} 618$ it was ordered that where persons of the rank of gentleman or above were buried without the attendance of an officer of arms, fees as high as $45 l$. were payable by the heirs. ${ }^{1}$

The pot boiled over in 1624 , in the last parliament of James I, with a slashing attack on the conduct of the heralds at their visitations of the previous year and on the collection of funeral fees. The lead was taken by Coke, Mallory, Phelips, and Sir Francis Seymour, all of whom had a long career of opposition, and the first three of whom had suffered imprisonment for their conduct in the parliament of $\mathrm{I}_{2} \mathrm{I}$. Coke raised the question of the legitimacy of the new earl marshal's court, and urged that they "settle this now in Parliament." Wentworth, the Strafford of the next reign, joined in protest. ${ }^{2}$ This was a propitious moment for Brooke, the old enemy of the earl marshal's court, who now petitioned the Commons for redress of his grievances, and whose case together with the whole matter of the heralds' conduct was referred to a powerful committee including Coke, Philips, Mallory, Seymour, Selden, and others. They brought in a very damaging report, to the effect that the visitations as then conducted constituted a grievance, that the heralds' fees were excessive, and "their service unprofitable, and without precedent, and not warranted by law." The House confirmed this by voting the visitations as then conducted a grievance, although it was decided to postpone consideration of the jurisdiction of the earl marshal's court until the next session. ${ }^{3}$

Nothing more was done before the king's death in 1625, which terminated the parliament. Arundel's career, and the fate of the earl marshal's court remained imperilled, however, as the first years of the new reign revealed personal hostilities between Arundel and Buckingham, who remained the new king's favorite, as he had been his father's. Shortly after the reign opened Arundel was reported as having urged, in the Privy Council, "that titles should not be distributed broadcast as in the past, but only to persons of quality and of noble birth." Buckingham, presumably regarding this as a touch at his own rise and his share in the sale of peerages, warmly replied that such advice amounted to aspersing the memory of the late king. ${ }^{4} \mathrm{~A}$ little later the two were again at odds over the rights of the Richmond Herald, a

1 Steele, Bibliography of Royal Proclamations, I, no. I225; cf. C.S.P., Dom., x6ri-r8, p. 593, and T. W. King, ed., Lancashire Funeral Certificates (Chctham Soc., LXXV, I 869), p.v. Fees totalling 380 l. ros. were levied at a funeral in I639 (C.S.P., Dom., 1639 [1873], p. .22).

2 Journals of the House of Commons (n.p., n.d.), I, 692-93.

3 Ibid., I, 701, 704.

4 Calendar of State Papers and Manuscripts relating to English Affairs existing in the Archives and Collections of Venice, ed. A. B. Hind, XIX, London I914, I2. 
client of Buckingham. ${ }^{1}$ Arundel himself fell into disgrace with Charles in 1626 , was dismissed from the court and imprisoned in the Tower, not being reconciled with the king until 1628 .

Better days were ahead, however, for from $16_{30}$ to 1640 , that is, during the personal rule of Charles $I$, the court of earl marshal was in its heyday. In the absence of parliament, public criticism was curtailed and except for occasional jurisdictional disputes with the other courts hardly a voice was raised against it. We possess notes relative to many of the cases heard, together with an excellent description of the court by William Segar, Garter. The court was held either at Westminster, in the Painted Chamber, or at Arundel's house, "where in the great hall he hath a large table or stage four square, built with rails thereabout, and benches therein, and an half pace raised above the same..." Within the rails sat the officers, the pursuivant messenger, crier, a doctor of civil laws "to resolve doubts," and a registrar or clerk. Outside the rails sat lawyers, serjeants, counsellors of law, and sometimes doctors and proctors of the civil law. ${ }^{2}$

Accounts of a number of cases tried in this period have survived. ${ }^{3}$ There were a few suits over usurped arms, ${ }^{4}$ and several interesting cases arising out of the martial law jurisdiction. ${ }^{5}$ Most of the cases of which records survive appear, however, to have been concerned with defamation or scandalous words, and were brought before the earl marshal in virtue of the authority outlined in the proclamations of I6I 3-I4. The former of these, dated is October I6I3, after referring to the outlawing of duels, and the custom of publishing vindications by aggrieved persons, enjoined any man so misrepresented to appeal to the Commissioners for the Earl Marshal, and apparently this was now interpreted as conveying the right to hear pleas of slander. Although

1 C.S.P., Dom., I627-28 (1858), Pp. 230-31.

2 William Segar, The Earl Marshal his Office, in John Guillim, A Display of Heraldry, London 1724 , pt. ii, 40-4I.

3 Rushworth took notes of some which he published in his Historical Collections, II, pt. ii, I054-56. James Dalloway printed some from mss. in the College of Arms in his Inquiries into... Heraldry in England, pp. 295-302.

4 De La Warr vs. West, in Rushworth, II, pt. ii, ro54-55; Blount vs. Moore, in Grazebrook, The Earl Marshal's Court, p. ixx.

5 Dispute for precedence in Holland between the Earls of Oxford and Southampton, who were both colonels of regiments in the service of the Elector Palatine (C.S.P., Dom., I623-25, Pp. 297, 3 I I); charges arising out of the expedition to La Rochelle (ibid., I 628-29 [r859], p. 419); sentence of death against William Homes (ibid., I634-35 [I864], p. 436); committing by the earl marshal of individual persons for failure to find arms (ibid., I627-28, p. 588 ; newsletter of 25 Sept. 1635 in Bodleian Library MS. Carte 77, ff. 423-24). See W. S. Holdsworth, Martial Law Historically Considered, in his Essays in Law and History, ed. A. L. Goodhart and H. G. Hanbury, Oxford 1946. 
the trial in the court of earl marshal of cases of defamation was thus an innovation, and eventually proved to be one of the main causes of the attack on the court, there was ample reason why remedies should have been sought here. In the middle ages the remedy for defamation lay with the manorial and local courts. Their jurisdiction eventually decayed, and in most cases plaintiffs in such a suit on the eve of the Tudor period would probably have gone to an ecclesiastical court. In the sixteenth century the common law courts began to compete in this field, and soon deprived the ecclesiastical courts of the greater part of their jurisdiction. In fact, the common law courts were overwhelmed with litigation involving defamation, and by 1617 Coke was complaining of the frequency of these actions. The answer was to discourage such cases, and this was done first by ruling that in the common law courts "mere spoken words defamatory to a private person cannot be treated as a crime," which had the effect of driving the plaintiff to lodge a civil suit. Here, however, the rule was applied that "however insulting the words, no action lay unless the court could see that damage must ensue as a natural and probable result of the words spoken." The courts, desiring to discourage these actions, construed insulting words very narrowly, and interpreted them as innocently as possible, thus making a verdict for the plaintiff difficult to secure. The common law, therefore, "gave no adequate remedy for defamation." 1

The consequence of these developments was that the man who apprehended difficulty in a common law court in a case of defamation would welcome the opportunity to plead elsewhere. Some doubtless went to the Star Chamber, but the practise there appears mainly to have dealt with criminal cases, and the Star Chamber, moreover, did not usually assess damages. What was more natural, duels having been outlawed, than that gentlemen who considered themselves aggrieved or defamed, especially by persons of low degree, should lay their appeals before the earl marshal? ${ }^{2}$ At any rate such pleas assumed an ever increasing importance. A few verged on the frivolous. One quarrel which was brought before the court arose from differences as to whether a hare was killed fairly. ${ }^{3}$ Another concerned the curate of St. Clement Danes. He was sued for admonishing a parishioner who was a servant in the household of the king for drunkenness and 1 W. S. Holdsworth, Defamation in the Sixteenth and Seventeenth Centuries, Law Quarterly Review, XL (1924), 407-8; cf. Holdsworth, A History of English Law, V, Boston I 27, 206; VIII (I 226), 334-47, and Van Vechten Veeder, The History of the Law of Defamation, in: Select Essays in Anglo-American Legal History, Boston 1909, III, 446-73, esp. p. 464.

2 C.S.P., Dom., 1619-23, p. 436.

3 James Spedding, Letters and the Life of Francis Bacon, VII, London I874, 529-30. 
incontinency. ${ }^{1}$ Insofar as the earl marshal's decision averted violence there can be no question of the court's good services, for the readiness to resort to arms over punctilios is all too familiar a characteristic of the age. But morally the changeover was indefensible, for it often involved the trial of differences between gentlemen and commoners in a court dedicated to the preservation of class privilege. One Christopher Copley was fined $300 \mathrm{l}$. for scandalous words spoken of the Earl of Kingston in a dispute as to the relative antiquity of their descents. ${ }^{2}$ Lord Powis sued one Edward Vaughan for words concerning the legitimacy of his daughter's child. ${ }^{3}$ Numerous cases between lesser persons were tried, although on at least one occasion a complaint was referred by the earl marshal to the justices of the peace. ${ }^{4}$ There is a curious instance of the East India Company's appealing to the court to punish one of its members for his attacks on the directors. The Earl Marshal ordered the man to submit and acknowledge his wrongs, and "with some reluctancy and repyning" he did so. ${ }^{5}$ The court can hardly be regarded as an instrument of royal tyranny, for most if not all the cases before it were brought by private persons. The decisions usually required a submission and apology by the guilty party, and often involved damages, a heavy fine, together with security to keep the peace. The temptation to elude the jurisdiction of the court must have been strong, but Peter Apsley's fate demonstrated the folly of this course. Facing trial by the court for his share in a quarrel in $I 6_{3} \mathrm{I}$, he escaped to the Low Countries. Subsequently being pardoned, at the instance of the Earl of Northumberland, Apsley insolently sent a letter of challenge to his benefactor. Finally he returned and surrendered, whereupon in the Star Chamber he was fined 5000 l., imprisoned during pleasure, perpetually banished from court, declared incapable of ever holding office, prohibited from ever wearing a sword in England, and required to make public submission to the king, the earl marshal, and Northumberland. ${ }^{6}$

The authority of the earl marshal's court did not go unquestioned, for there was a hot struggle in $16_{3} x$ with the judges of the King's

1 C.S.P., Dom., I637 (1868), pp. 569-70.

2 Rushworth, Historical Collections, II, pt. ii, I055-56; C.S.P., Dom., I635-36 (I866), p. 435; 1636-37 (1867), p. 495; 1637, pp. 52-53.

3 C.S.P., Dom., $1639-40$ (1874), p. 261.

4 Hist. MSS. Comm., Various Collections, I ( I gor), ro5.

5 A Calendar of the Court Minutes, etc. of the East India Company, 1635-1639, ed. Ethel Bruce Sainsbury, Oxford 1907, pp. xxxiv-xxxvi; 1640-43, Oxford 1909, p. 33.

- Stecle, Bibliography of Royal Proclamations, I, no. 1636; C.S.P., Dom., 1631-33, p. 135 ; 1633-34, pp. 93, 442, 464; Hist. MSS. Comm., Portland MSS., II (I 893), I 24. Apsley was quarreling again in 1636 (The Court and Times of Charles the First, ed. R. F. Williams [London, I 848 ], II, 257-58). 
Bench, over a controversy between one Jones, a churchwarden in London, and Thomas Thompson, Lancaster Herald, about a seat in Hackney Church. Jones had been imprisoned by the earl marshal, but was released on a writ of habeas corpus. The marshal imprisoned him a second time, but Jones successfully applied to the King's Bench for a habeas corpus, only to be seized immediately by the marshal's officers a third time. ${ }^{1}$ The matter was discussed before the council, where angry words were exchanged, and where one of the justices was denounced as a "saucy fellow." Nevertheless the judges resolved to relieve Jones, "and to stand to the maintenance of their court, being, as they affirm, the highest and ancientest next the parliament." They acknowledged themselves "to be but poor mean men, and my Lord of Arundel to be a person of high birth and eminent fortune, yet .... when they sat in judgment upon the bench, they were not to yield to him." 2 The outcome of the dispute is unknown, but the controversy was not forgotten and was brought up in parliament in $164 \mathrm{I}$.

A fresh series of visitations took place in $1 \sigma_{33}$ and $16_{34}$, again by deputies, and covering the midland and home counties and certain outlying shires, all among the richest in the kingdom. ${ }^{3}$ The proceedings of the heralds are amply illustrated in the state papers for these years. They summoned the gentlemen of the counties to appear before them or to send their pedigrees, cited those who refused before the earl marshal, ordered correction of arms, and collected fees after funerals. ${ }^{4}$ Their conduct provoked the usual complaints, which five years later were also to be brought forward in the Commons.

When, after eleven years of personal government, parliament was finally reassembled in 1640 it was almost a foregone conclusion that remedies would be sought against such powers as the earl marshal had wielded. In the Short Parliament of that year, after listening to Pym recount a catalogue of the grievances of the subject, a young attorney representing a Wiltshire borough rose to make his maiden speech. Just 31, Edward Hyde, a member of the Middle Temple, had built up a good practise, and was now embarking on his political career. The previous speaker, he said, had left unmentioned one particular grievance, the court of the earl marshal. Hyde related a

1 The Journal of Sir Simonds D'Ewes, ed. Wallace Notestein (New Haven, I923), pp. $375-7^{6}$.

2 Court and Times of Charles the First, ed. Williams, II, 97-98.

3 The commission to Clarenceux and Norroy is printed in Noble, History of the College of Arms, pp. 222-23.

4 C.S.P., Dom., 1634-35, pp. 148, 156, 157, 179, I 86. 
number of examples of the more outrageous proceedings of the court. He told the story of the citizen who objected to being overcharged by a waterman, and who, when the waterman attempted to overawe him with his badge, "bade him be gone with his goose." But it developed that the badge represented a swan, the crest of an earl, by whom the waterman was employed. The citizen was both fined and imprisoned for dishonoring the earl's crest by calling the swan a goose. Hyde also excoriated the heralds for their exactions at funerals: the grievances denounced by the previous speakers ended with the grave, he said, but the funeral fees were taxes on the dead. ${ }^{1}$ Owing to the almost immediate dissolution of the Short Parliament Hyde was unable to follow up this attack until November 1640 , but in the Long Parliament he again moved against the earl marshal's court, this time emphasizing the court's usurped jurisdiction over "contumelious and reproachful words, of which the law took no notice." 2 Others agreed as to the illegality of such proceedings: as D'Ewes observed, in regard to any records which could justify them, "my opinion alwaies was and still is, that they are written or inrolled in dorso of the Donation of Constantine." 3 Selden decried the exercise in the court of what he called "Imperial law," by which he meant the Roman civil law, which was valid only insofar as warranted by custom. Modern scholarship holds that the view that the common law was endangered by the civil law at this time is exaggerated; ${ }^{4}$ nevertheless the common lawyers professed to see in the exercise of civil law a threat to the English system. ${ }^{5}$ Probably their attitude was determined by professional jealousy. As D'Ewes remarked, "those Civilians onlie who practiced in that court and made a gaine ther weere in the fault." " 6 The excessive demands of the heralds were also called into question. ${ }^{7} \mathrm{~A}$ committee headed by Hyde was therefore appointed, which held hearings where the grievances of a decade were aired. ${ }^{8}$ After some excited meetings the

1 The Life of Edward Earl of Clarendon... written by Himself (Oxford, I 857), I, 67-68; copy of the speech in Bodleian Library, MS. Clarendon $18, f$. 155.

2 Life of Clarendon, I, 70-71; Bulstrode Whitelocke, Memorials of the English Affairs (2d ed., Oxford, 1853), I, 147 .

3 Journal of D'Ewes, ed. Notestein, p. 378.

4 Theodore F. T. Plucknett, A Concise History of the Common Law, and ed., Rochester (N.Y.) 1936, pp. 264-65.

5 Arthur Duck, the King's Advocate in the carl marshal's court, and a noted civilian, wrote: "the common lawyers blame us for pursuing the useless learning of foreign laws, and accuse us of being citizens of a foreign state and strangers in our own" (De Usu et Authoritate Juris Civilis, qu. in Holdsworth, History of English Law, V, 24-25).

- Journal of D'Ewes, ed. Notestein, p. 378.

7 Ibid., pp. 54-55.

8 Ibid., pp. 68, 76, 96-98, I 25, 226-27, 242-44, 366; Journals of the House of Commons, II, 34; Noble, History of the College of Arms, p. 225. 
committee reported unfavorably on the earl marshal's holding plea of words (that is, hearing cases of defamation), and although several members urged that if the earl marshal had no power to punish words duels might ensue, the tide was clearly in the other direction. Accordingly the Commons voted against the jurisdiction over words, resolved that the earl marshal could hold no court without the constable, and that the earl marshal's court was a grievance. ${ }^{1}$ The last step was to include, in the Grand Remonstrance, that "the pretended Court of the Earl Marshal was arbitrary and illegal in its being and proceedings." 2

Thus one of the most important jurisdictions of the earl marshal's court was brought to an end, and the whole constitutionality of the court called into question. For Hyde the victory was a personal one which brought him much credit. The votes of the Commons mark a turning point in the history of the court, for never again did it attempt to hold plea of words, and although it survives to this day its functions have since $164 \mathrm{I}$ been confined to heraldic cases.

Legally and constitutionally the decision against the earl marshal represents the same sentiment which brought about the fall of Star Chamber, High Commission, ship money, forced knighthood, and the other instruments of personal rule. As D'Ewes remarked, the pretensions of the earl marshal's court "struck at the three great rights of the subjects of England, of our lives, liberty, and estates." 3 The court was erroneously judged by M.P.s to be an innovation, "sett upp when ther was noe moore hope of Parliaments, and when the Common law was declining in its power and honor." "It was disastrous for the court that just when the attack was launched some members of parliament themselves were being sued there. ${ }^{5}$ While Arundel himself was exempted from blame, his deputies were excoriated, including his son Lord Mowbray and Maltravers, who acted for the earl during his frequent travels abroad, and who was apparently the most violent of men. ${ }^{6}$ The common lawyers and judges who objected to the prerogative

1 Journal of D'Ewes, ed. Notestein, pp. 375-79; Journals of the House of Commons, II, 89. 2 S. R. Gardiner, ed., Constitutional Documents of the Puritan Revolution, 3rd ed., Oxford I go6, P. 213.

3 Journal, ed. Notestein, p. $9^{8 .}$

4 Ibid., pp. 375-79.

5 Michael Wharton, M. P. for Beverley (Journals of the House of Commons, II, I6), and George Searle, M. P. for Taunton (Journal of D'Ewes, ed. Notestein, pp. 226-27).

6 "Upon Saturday in the evening in a committee in the Lords House the Lord Mowbray (viz., the Earl of Arundel's eldest son) gave the Earl of Lindsey, High Chamberlain, the lie, whereupon the Earl of Lindsey struck him over the head with his white staff, and the other threw an ink horn into his face." (Hist. MSS. Comm., Cowper MSS., II [1888], 289-90). 
courts were motivated by the same sentiment in regard to the earl marshal's court. The lawyers were excluded from practising civil law, the judges saw in the court an encroachment on their own. Economically, the heralds constituted an entrenched monopoly in a day when monopolists were anathema, and whatever the ignorance of the interloping painters and stainers, they had public opinion behind them in objecting to the heralds' vested interests.

There may have been some regret at the downfall of the court: Sir Edward Walker, later Garter, had only praise for Arundel's efforts to preserve "the honor and reputation of the nobility and gentry", and held that "if all men in power had but had the same inclinations, the great and fatal period these times have brought on all of them possibly had not been." ${ }^{1}$ Few of his contemporaries would have supported Walker in this view. There was little sympathy for the heralds, especially as they themselves were, figuratively speaking, chronically at each other's throats. So low was their reputation at the time of Hyde's attack that a mock organization had been formed by the painters, who used a public house commonly called the Heralds' Office, which was located near the College of Arms. Here, as it was charged, they undertook "to do everything relating to the faculty of a herald." "

It should be observed that there was no general attack on heraldry as such. There may have been some puritans who, as Macaulay observed, were assured that "If their names were not found in the registers of heralds, they were recorded in the Book of Life." 3 Nevertheless a few years after the civil war began the parliamentarians set up their own organization to regulate heraldry, and as is well known, both arms and titles were granted by Cromwell as Protector. ${ }^{4}$ The purely heraldic jurisdiction of the earl marshal and officers of arms was regarded as fully restored in 1660 , and continues to this day. Nevertheless their authority steadily waned. Success required a rigid and precise stratification of classes, whereas English society in this period was fluid and status was indistinctly defined. Economy and apathy also obstructed the efforts of the heralds after the Restoration: one Lancashire worthy, who might have established his gentility, preferred, in 1666 , to disclaim any pretence to arms rather than incur the expense of registration, ${ }^{5}$ while at the visitation of Oxfordshire

${ }_{1}$ Sir Edward Walker, Historical Discourses upon Several Occasions, London 1705, p. 212.

2 Englefield, History of the Painter-Stainers, pp. I I 9-20.

3 Critical and Historical Essays, ed. F. C. Montague, London I903, I, 50.

4 Acts and Ordinances of the Interregnum, 1642-I660, ed. C. H. Firth and R. S. Rait, London I9II, I, 266, 604. The ordinance of 1646 for regulating the heralds' office was "opposed by many inclining to levelling." (Whitelocke, Memorials, I, 586).

5 Grazebrook and Rylands, Visitation of Shropshire, pt. i, p. xxxiv. 
in 1668 only a few gentleman appeared, because of the superior attraction of a horserace in a neighboring county. ${ }^{1}$ Finally, there can be no doubt that the intellectual atmosphere of the Restoration period militated against the extreme claims made in support of pedigrees and arms. A new critical spirit was abroad, which regarded as both vulgar and ridiculous those vain affectations "to fly beyond the moone" in matters of pedigree. ${ }^{2}$ The age of scientific genealogy lay in the future, but the age of credulity was drawing to a close.

1 William H. Turner, The Visitations of the County of Oxford (Harleian Soc., 1871), p. xi.

2 Gervase Holles, Memorials of the Holles Family, I493-I656, cd. A. C. Wood (Camden 3rd Ser., LV, 1937), p. 3. 